\title{
Analysis of traditional fish processing methods among women in Lau Local Government Area of Taraba State, Nigeria
}

\author{
Usman, I. S. *, Abdullahi, A. and Waziri, U. M. \\ Department of Agricultural Economics and Extension, Modibbo Adama University of Technology, Yola, Nigeria. \\ ${ }^{\star}$ Corresponding author. Email: ibrogirei2@mautech.edu.ng
}

Copyright (@) 2017 Usman et al. This article remains permanently open access under the terms of the Creative Commons Attribution License 4.0, which permits unrestricted use, distribution, and reproduction in any medium, provided the original work is properly cited.

Received 29th April, 2017; Accepted 25th May, 2017

\begin{abstract}
The study analyzed traditional fish processing methods among women in Lau Local Government of Taraba State, Nigeria. Structured questionnaires were administered to 80 randomly selected respondents from 113 registered fish processors. Percentages, frequencies and multiple regression analysis were used for the data analysis. The study revealed that most $(73.75 \%)$ of the respondents were within the age range of 30 to 49 years, $73.75 \%$ were married with average size of seven people per house hold. About $73 \%$ of the respondents had formal education with average of 19 years processing experience. More than half $(51.25 \%)$ of the respondents had income of less than $\mathrm{N}$ 30,000 and $90.00 \%$ of them had no prior contact with extension agents. $77.50 \%$ of the respondents adopted smoking and $10 \%$ fermentation/drying as methods of fish processing. The coefficient of determination $\left(R^{2}\right)$ was estimated at 0.974 indicating that $97.4 \%$ of the variation was explained by the variables (Age, house hold size and education) included in the model. Smoke pollution, poor transportation network and seasonality of fish were the major problems confronting the respondents. The findings recommended that the fisheries unit of agricultural extension agency and research institutes should device appropriate or improved methods of processing fish locally that will be less hazardous to health and environmentally suitable. Government should engage in rehabilitation of rural feeder roads leading to the processing communities to improve transportation system and reduce cost.
\end{abstract}

Keywords: Fish processing, traditional, Taraba State, women.

\section{INTRODUCTION}

Fish is becoming increasingly important in the diet of Nigerians as the cost of beef increases daily. Fish contribute about $55 \%$ to the protein intake of Nigeria (Abu, 2015). The demand for fish is very high due to its importance in human nutrition and for animal feed (fish meal and poultry feeds). Its biological value in terms of high protein content and other nutrients account for the consumption of fish products as compared to other animal protein sources (Oluwatoyin et al., 2010). Its amino acid profile, low cholesterol, high vitamins and mineral content, as well as fatty acid profile makes it stands out among sources of animal protein (Adewuyi et al., 2010). Fish is susceptible to deterioration due to accelerated action of proteolytic enzymes and subsequent microbial degradation, hence appropriate preservative measures required (Modu, 2015). Most of the fish marketed throughout Nigeria are captured from inland waters along the Benue-Niger Rivers, the Kainji Lake, the Lake Chad and other numerous Dams (Modu, 2015). Most of the fish caught are either sold immediately or processed to enhance better storage.

There are many methods of preserving fishes. The modern method: chilling or freezing are employed to facilitate transportation by road, rail, sea or air in insulated containers and are suitable for refrigeration on transient (Abu, 2015). Lack of these facilities in rural areas necessitates adoption of traditional methods to ensure delivery to urban centres without spoilage (Yakubu, 2013).

Davies and Davies (2009) observed three traditional 
processing methods; air drying, hot smoking and salting method. Hot smoking was the most widely adopted processing method, followed by salting and air drying. Ibrahim et al. (2011) reported that, the most prominent methods of processing fish from Lake Feferuwa are smoking and drying, due to power shortages. However Oluwatoyin et al. (2010) reported that salting, sun drying, smoke drying and frying were the most popular processing and preservation techniques utilized by women, as the procedure enhances desirable taste.

Various studies have been conducted on the fish processing methods, but little work is done in the study area being one of main sources of fish in Taraba State. Therefore, the study was conducted to analyze the traditional methods of fish processing among women in Lau Local Government Area of Taraba State. The specific objectives of the study were to:

1. describe the socio-economic characteristics of the respondents in the study area;

2. identify the traditional method used for processing by the respondents;

3. determine the relationship between socio-economic variables and use of traditional methods of fish processing and

4. identify the problems encountered by the respondents in the study area.

\section{METHODOLOGY}

\section{Study area}

The study was conducted in Lau Local Government Area of Taraba State, which lies between latitude $10^{\circ} 18^{\prime}$ and $80^{\circ} 13^{\prime}$ North of the Equator and longitude $10^{\circ} 48^{\prime}$ and $90^{\circ} 40^{\prime}$ East of Greenwich Meridian (Post Offices- with map of LGA, 2012) with the land area of $1,660 \mathrm{~km} 2$ and population of 96,590 people (NPC 2006). The climate is one which alternate between wet and dry season, mean average rainfall of $1020 \mathrm{~mm}$ and maximum temperature of about $42^{\circ} \mathrm{C}$. Fishing, farming and marketing are the major occupation of the people in the area. The Local Government area is the leading producer of fish in the State due to its numerous water bodies.

\section{Method of data collection}

The data for the study were collected from primary source with the aid of structural questionnaire administered to 80 respondents in the study area.

\section{Sample size and sampling procedure}

The list of 113 registered fish processors was obtained from the secretary of the fish processors in the Local Government Area, to form the sample frame. A total of 80 respondents were selected randomly.

\section{Method of data analysis}

Percentage, mean and frequency distribution were used to achieve objective i, ii and iv, while multiple regression analysis by means of ordinary least square (OLS) was used to achieve objective iii. It is specified as:

$\mathrm{Y}=b_{0}+b_{1} X_{1}+b_{2} X_{2}+b_{3} X_{3}-b_{4} X_{4}+u$

Where: $Y=$ Traditional fish processing method (\% of the total number of traditional methods used), $X_{1}=$ Age (years), $X_{2}=$ Household size (number of persons), $X_{3}=$ Processing experience (years), $\mathrm{X}_{4}=$ Educational level (years spent in School), $b_{1}-b_{4}=$ Coefficient of independent variables, $b_{1}=$ Constant and $U=$ error term .

\section{RESULTS AND DISCUSSIONS}

The result in Table 1 indicated that most $(73.75 \%)$ of the respondents were within the age range of 30 to 49 years with an average age of 41 years. This implies that most of the respondents were within their active ages and can therefore carry out fish processing activities with vigor. The possible explanation of respondents below 30 years may be because they were still dependent or in school. This is in line with the findings of George et al. (2014) that the majority of respondents were between 30 to 49years of age in a study he conducted in Ibeju-Lekki Local Government Area, Lagos State, Nigeria.

The study also revealed that most $(73.75 \%)$ of the respondents were married with an average household size of 7 people which may be a source of family labour. This implies that there are more married individuals as processors and this may be because married individuals have more responsibilities to take care of their household. The result corroborate with the findings of Olabunmi and Adebukola (2012) who also reported that married women were dominant in a study conducted in Ibarapa Area of Oyo State, Nigeria.

The educational level of the respondents indicated that most $(72.50 \%)$ had primary and secondary education. The dominance of respondents with primary and secondary schools educational level could be as a result of early marriage of most of the respondents in rural areas. About $81 \%$ of the respondents had 11 to 30 years of experience (Table 1) with a mean of 19 years, while only $12.50 \%$ had less than 10 years of experience. This implies that they had enough experience to enhance their performance in the business. Experience brings about specialization in a trade (Abdullahi et al., 2016).

The result on Table 1 also shows that $51.25 \%$ of the respondents had income of between $\mathrm{N} 20,000$ to $\mathrm{N} 29$, 000 and only $1.25 \%$ of the respondents had an income above N49, 000. This shows that majority of them has low income from fish processing. The result also shows that only $8.00 \%$ the respondents had contact with extension agents between one to two times in a year 
Table 1. Socio-Economic characteristics of respondents $(n=80)$.

\begin{tabular}{|c|c|c|c|}
\hline Variables & Frequency & Percentage (\%) & Mean \\
\hline \multicolumn{4}{|l|}{ Age } \\
\hline $20-29$ & 9 & 11.25 & \multirow{4}{*}{41} \\
\hline $30-39$ & 26 & 32.50 & \\
\hline $40-49$ & 33 & 41.25 & \\
\hline$>50$ & 12 & 15.00 & \\
\hline \multicolumn{4}{|l|}{ Sex } \\
\hline Male & 4 & 5.00 & \\
\hline Female & 76 & 95.00 & \\
\hline \multicolumn{4}{|c|}{ Marital status } \\
\hline Single & 10 & 12.50 & \\
\hline Married & 59 & 73.75 & \\
\hline Widowers & 11 & 13.75 & \\
\hline \multicolumn{4}{|c|}{ Household size } \\
\hline $0-5$ & 24 & 30.00 & \multirow{3}{*}{7} \\
\hline $6-10$ & 46 & 57.50 & \\
\hline$>11$ & 12 & 12.50 & \\
\hline \multicolumn{4}{|c|}{ Education level } \\
\hline No-formal & 12 & 15.00 & \\
\hline Primary & 33 & 41.25 & \\
\hline Secondary & 25 & 31.25 & \\
\hline Tertiary & 10 & 12.50 & \\
\hline \multicolumn{4}{|l|}{ Experience } \\
\hline $1-10$ & 10 & 12.50 & \multirow{4}{*}{19} \\
\hline $11-20$ & 34 & 42.50 & \\
\hline $21-30$ & 31 & 38.75 & \\
\hline $31-40$ & 5 & 6.25 & \\
\hline \multicolumn{4}{|c|}{ Income (‘000) } \\
\hline $20-29$ & 41 & 51.25 & \multirow{4}{*}{21,125} \\
\hline $30-39$ & 33 & 41.25 & \\
\hline $40-49$ & 5 & 6.25 & \\
\hline$>49$ & 1 & 1.25 & \\
\hline \multicolumn{4}{|c|}{ Extension contact } \\
\hline Yes & 8 & 8.00 & \\
\hline No & 72 & 90.00 & \\
\hline
\end{tabular}

Source: Field survey, 2016.

while the remaining $90.00 \%$ of the respondents had no extension visit at all. This has negative effect on their performance.

\section{Methods used in fish processing traditionally}

The method used in fish processing in the study area were identified and presented in Table 2. The most adopted method as revealed by the study was smoking $(77.50 \%)$. Smoke is produced from burning of hard wood under wire mesh with fish sprayed on it. The longer the fish is smoked, the longer the shelf life. According to the respondents, smoke fish is most preferred by consumers after fresh fish. Sun-drying (33.75\%) is the second widely used method which involves dehydration (the removal of 
Table 2. Distribution of respondents according to methods of processing.

\begin{tabular}{lccc}
\hline Methods & *Frequency & Percentage (\%) & Rank \\
\hline Smoking & 62 & 77.50 & 1 \\
Sun-drying & 27 & 33.75 & 2 \\
Frying & 14 & 17.50 & 3 \\
Salting & 10 & 12.75 & 4 \\
Fermenting/Drying & 08 & 10.00 & 5 \\
\hline
\end{tabular}

Source: Field survey, 2016. *Multiple Responses exist.

Table 3. Relationship between socio-economic variables and number of fish processing method used by respondents.

\begin{tabular}{lccc}
\hline Variables & Coefficient & Standard error & T-value \\
\hline Age $\left(\mathrm{X}_{1}\right)$ & 0.219 & 0.007 & $2.935^{\star}$ \\
House hold size $\left(\mathrm{X}_{2}\right)$ & 0.215 & 0.060 & $5.996^{*}$ \\
Experience $\left(\mathrm{X}_{3}\right)$ & 0.660 & 0.017 & $1.231^{\mathrm{NS}}$ \\
Educational level $\left(\mathrm{X}_{4}\right)$ & -0.543 & 0.010 & $-9.977^{\star *}$ \\
Constant & & 0.250 & $6.647^{* *}$ \\
$\mathrm{R}^{2}$ & 0.974 & & \\
Adjusted $\mathrm{R}^{2}$ & 0.972 & & \\
F-ratio & 333.406 & & \\
\hline
\end{tabular}

Source: Field survey, 2016. ${ }^{*}=$ Significant at $5 \%,{ }^{* *}=$ Significant at $1 \%$, NS= Not Significant.

moisture content of fish to prevent bacterial decomposition). When moisture content is reduced to $10 \%$ and stored in dry place will prevent spoilage. The result agrees with the findings of Oluwatoyin et al. (2010), who reported that smoking was the most preferable practice among women as it enhances desirable taste, flavor, and increase shelf life. The fourth method of processing adopted by $10 \%$ of respondents is fermentation. Fishes are stored enclosed in containers; allow to stand overnight, for fermentation process and subsequently sun dried.

\section{Relationship between socio-economic variables and number of fish processing method used by respondents}

The regression result (Table 3 ) revealed the coefficient of determination $\left(R^{2}\right)$ to be 0.974 , indicating that $97.4 \%$ of the variation was explained by the variables. The variables of Age $\left(X_{1}\right)$ and House hold size $\left(X_{2}\right)$ have positive coefficients and statistically significant at $5 \%$ level. This implies that an increase in age and number of people in house hold will facilitates the number of traditional fish processing methods adopted. Education $\left(\mathrm{X}_{4}\right)$ has a negative but statistically significant relationship at $1 \%$ level. This implied that the higher the educational status of the respondent the lesser the chances of participation in the business.

\section{Problems confronting fish processors}

The Problems confronting fish processors in the study area were identified and ranked in order of severity (Table 4). The most severe problem was; smoke pollution $(51.25 \%)$ whose adverse effects manifested in the eyes and chest of respondents. .Transportation ranked second $(31.25 \%)$, due to poor state of feeder roads. Similarly cold season has negative impact as observed, as most of the processors relied on fishes captured from wild. There was a contrary report to the findings of Ibrahim et al. (2011), who reported lack of collateral to secure bank loan as the major problem experienced by women fish processors in Lake Feferuwa fishing community of Nasarawa State, Nigeria.

\section{Conclusion}

The study revealed that traditional fish processing in the study area was mainly adopted by women whose family size and educational status had positive impact on the business. The result of the multiple regressions showed that age and house hold size had positive impact on the number of traditional methods used, while education level indicated negative impact on the number of traditional method used. Smoke pollution, poor transportation network and seasonality of fish were the major problems confronting traditional fish processors in the study area. 
Table 4. Distribution of respondents according to the problems faced in Fish processing activity.

\begin{tabular}{lccc}
\hline Methods & ${ }^{*}$ Frequency & Percentage (\%) & Rank \\
\hline Smoke pollution & 41 & 51.25 & 1 \\
Transportation problem & 25 & 31.25 & 2 \\
Seasonality of fish & 20 & 25.00 & 3 \\
Inadequate storage facilities & 17 & 21.25 & 4 \\
Delay in supply of fresh fish & 15 & 18.75 & 5 \\
Tedious and Time consuming & 13 & 16.25 & 6 \\
Cost of processing equipment & 8 & 10.00 & 7 \\
\hline
\end{tabular}

Source: Field survey, 2016. *Multiple responses.

\section{Recommendations}

Services of agricultural and health extension workers required more in rural areas. The fisheries unit of agricultural extension agency and research institutes to come up with appropriate or improved method of processing fish locally, with lesser health implication and environment friendly.

\section{CONFLICT OF INTEREST}

The authors declare that they have no conflict of interest.

\section{REFERENCES}

Abu, A. (2015). A Study of Microorganisms Associated with Fish Spoilage in Lokoja, Niger State, Nigeria. Agricultural Economics, 9(4), 68-75.

Adewuyi, B. B., Philip, I. A., Ayinde, I., \& Akerele, D. (2010). Analysis of profitability of fish farming in Ogun State, Nigeria, SHUM Ecol, 31(3), 179-184.

Abdullahi, A., Usman, I. S., Girei, A. A. \& Ismaila, G. (2016).Examination of Indigenous Storage Methods of Cowpea (Vigna unguiculata) in Mubi South Local Government Area, Adamawa State, Nigeria. Scientific Papers "Management, Economic Engineering in Agriculture and Rural Development", 16(3), 9-16.

Davies, R. M., \& Davies O.A. (2009).Traditional and improved fish processing in Bayelsa State, Nigeria. European Journal of Science Resource, 26, 539-548.
George, F. O. A., Ogbolu, A. O.,Olaye, O. J., Obasa, S. O., Idowu, A. A., \& Odulate, D. O. (2014). Fish processing technologies in Nigeria, A case study of ibeju-lekki local government area, Lagos State, Nigeria, American journal of food technology, 9(6), 302-310.

Ibrahim, H. I., Kigbu, A. A., \& Mohammed, R. (2011). Women's experiences in small scale fish processing in Lake Feferuwa fishing community, Nasarawa State, Nigeria. Livestock Research for Rural Development, 23(3), 2011.

Modu, B. (2015). Fish processing and Marketing in Maiduguri Metropolitan, Borno State, Nigeria. Journal of Biological Sciences, 6(3), 45-53.

National Population Commission of Nigeria (2006). Report of National census. Federal Republic of Nigeria Official Gazette. The Federal Government Printer, Lagos, Nigeria.

Olabunmi, A. and Adebukola, F. B. (2012). Determinant of Income from Fish Marketing in Ibarapa Area of Oyo State, Nigeria. Science Journal of Agricultural Research and Management, 6p.

Oluwatoyin, D. K., Stella B. W., \& Awujola, A. F. (2010). Indigenous fish processing and preservation amongst women in southwestern Nigeria, Indian journal of traditional knowledge, 9(4), 668-672.

Post Offices-with map of LGA (2012). NIPOST. Lau, NigeriaWikipedia. http://en-wikipedia.org/wikilau._Nigeria. Retrieved 2017-05-20.

Yakubu, M. D. (2013). Effectiveness of Traditional Fish Processing in Preservation of Fish, Hallmark Press, Kaduna, Pp. 67-114. 